\title{
AN INSCRIBED ROMAN SARCOPHAGUS FROM ELAZIĞ (EASTERN TURKEY) WITH AN APPENDIX ON A LATIN MILITARY INSCRIPTION
}

\begin{abstract}
:
We present a previously-unknown sarcophagus of the Roman period with a fragmentary and hard-to-decipher inscription in Greek, today exhibited in the grounds of the Archaeological and Ethnographic Museum of Elazı $\breve{g}$ in eastern Turkey. A personal name can still be deciphered on the front face of the sarcophagus: Menethymes. Elazığ Museum possesses a large collection of archaeological artefacts, especially from the rescue excavations at the höyük (tell or mound) sites in the area of the Keban dam construction in the 1960s and 1970s. The number of Roman artefacts in this museum is c. 100, excluding numismatic finds. This brief paper makes a contribution to the scanty knowledge of Roman-era funerary monuments in eastern Turkey. In the appendix, we also give the text of one of the most important finds at the same museum, a Latin military inscription from AD 64/65 on Gnaeus Domitius Corbulo and the Parthian war.
\end{abstract}

\section{ÖZet: ElaziĞ MÜZesI’NDeKI Roma Dönemi’ne Ait YAZITLI Bir LaHIT}

Bu kısa makalenin konusu olan lahit ilgili Müze Müdürlüğ̈̈’nün 4 Haziran 2018 tarih ve 34068228-155.01[155.01]E.481968 sayılı yazılı izni ile çalışılmıştır.

Bu kısa makalede, Elazığ Arkeoloji ve Etnografya Müzesi'nde sergilenen ve üzerinde iyi okunamayan Yunanca bir yazıt bulunan Roma Dönemi'ne ait bir lahit tanıtılmaktadır. Lahtin yazıtlı ön yüzünde Menethymes ismi çözümlenebilmiştir. Elazığ Müzesi, özellikle 1960'lı ve 1970'li yıllarda Keban Barajı inşaatı alanındaki höyüklerdeki kurtarma kazılarından elde edilen buluntulardan oluşan geniş bir arkeolojik eser kolleksiyonuna sahiptir. Müzedeki Roma Dönemi eserlerinin toplam sayısı nümizmatik buluntuları hariç 100'dür. Bu kısa makale, Doğu Anadolu'da Roma Dönemi'ne ait mezar anıtlarına ilişkin yetersiz bilgi dağarcığına katkıda bulunmaktadır. Makalenin somnundaki ek kısmında, aynı müzedeki en önemli buluntulardan biri olan, İ.S. 64/65 y1lında Gnaeus Domitius Corbulo ile Parthlar arasında geçen savaş hakkında bilgi veren Latince bir askeri yazıtı tekrar yayinliyoruz.

KEYWORDS: Sarcophagus, Museum of Elazığ, Elazığ, Harput, eastern Turkey, Roman period, Graeco-Roman epigraphy, Graeco-Roman onomastics, Roman archaeology, Latin military inscription.

AnAHTAR Kelimeler: Lahit, Elazığ Arkeoloji ve Etnografya Müzesi, Elazı̆̆, Harput, Doğu Anadolu, Roma Dönemi, Greko-Romen epigrafisi, Greko-Romen onomastiği, Roma arkeolojisi, Latince askeri yazıt.

\section{Introduction: the region of Elazı̆ in Graeco-Roman antiquity}

Elazığ (known as Mamuretülaziz in the Ottoman period) is a city in eastern Turkey surrounded by the vilayets (Turkish provinces) of Tunceli, Bingöl, Diyarbakır, Malatya and Erzincan (map 1). In ancient times it was located in the uppermost Euphrates valley. The plain on which the city extends is at an altitude of 1,067 m. The ancient town and its citadel, known as "Kharput" or "Kharpert" (fuupptinn or @upptinn), which means "rocky fortress" in Armenian, is located about five $\mathrm{km}$ south of modern Elazığ. However, very little written material about this city survives: the Early Muslim geographers knew it as "Hiṣn Ziyād", a term in use as late as the 16th century; however, the Armenian name, "Khartabirt" or "Kharbirt", whence "Kharput" and "Harput", was generally adopted over time. Harput is mentioned as "Charpete" (Xáp $\pi \varepsilon \tau \varepsilon)$ in Medieval Byzantine sources, and the region of Elazı̆



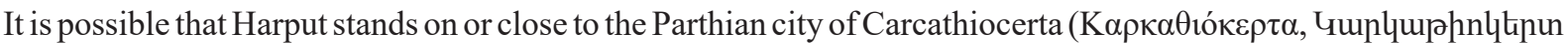
or Unlumphullinu, meaning "castle city"; perhaps modern Eğil in the province of Diyarbakır), referred to by 
Strabo (Geographica, 11.14.2) as "the royal city of Sophene", a province both of the ancient kingdom of Armenia (located in its south-west) and of the Roman Empire. ${ }^{1}$ Even though this region was of commercial importance during the Hellenistic period, we have very limited information about when and how Hellenistic culture spread there. $^{2}$ The area first fell under Roman influence with Pompey's campaign of 66/65 BC; after the War of the Armenian Succession in AD 58-63 it was conquered by Gnaeus Domitius Corbulo (see below). The region was under the sway of the Arsacid dynasty of Armenia (initially as a Roman client kingdom) until the overthrow of Artabanus IV in AD 224. ${ }^{3}$ Historically and archaeologically, however, the region and city of Elazığ are not wellknown in Graeco-Roman antiquity.

The first extensive archaeological researches carried out in the province of Elazığ were undertaken as a result of the rescue excavations during the construction of the Keban and Karakaya dams in the 1960s and 1970s, including the ones on the höyük (tell or mound) sites of Norşuntepe, Korucutepe and Sakyol (map. 2). During the Roman period there were very few large cities in the region and the small number of known Roman sites is mostly limited to the upper layers of the mounds excavated during the construction of these modern dams. One of the most important and extensively published mound sites yielding Roman finds is Aşvan Kale ${ }^{4}$, which is located $35 \mathrm{~km}$ northwest of Elazı $\breve{g}$, on the south bank of the Murat River, a tributary of the Euphrates, just west of Muratcık village. Another Roman site in the region is Taşkun Kale, which is located $31 \mathrm{~km}$ northwest of Elazı $\breve{g}$ and $4 \mathrm{~km}$ southeast of Muratc1k. ${ }^{5}$ This mound site was inhabited during the Late Hellenistic period and the Middle Ages. Pağnik is a further mound site located in Kaşpınar village, $3 \mathrm{~km}$ southeast of Ağın and $25 \mathrm{~km}$ northwest of Elazı ğ. In 1969-1970 excavations were also carried out in a nearby Roman limes under the direction of Richard P. Harper on behalf of the British Institute of Archaeology in Ankara. Yeniköy/Gavur Höyük is located $3 \mathrm{~km}$ north of Laluşag1 village in the northwestern part of the province of Elazı ̆. An excavation was carried out there in 1972 under the direction of Hamit Zübeyir Koşay in which the first building level was dated to the Roman and Early Byzantine periods. A Roman habitation is known at Tepecik/Makaraz Tepe.

\section{Archaeological and Ethnographic Museum of Elazĭg}

The first museum in Elazı ğ was established on 30th April 1965 in Alacalı Mescit (small mosque) in the district of Harput and was known as the "Harput Museum". In the following years, as this building was too small for the large number of archaeological artefacts and monuments, it was moved to a property belonging to the Municipality of Elazı̆̆ next to the post office on İstasyon Caddesi (Railway Station Street). This second building too became inadequate for the exhibition of the artifacts found in the surveys and excavations carried out within the framework of the Keban and Karakaya dam projects. The next museum was built on the campus of Firat University in 19711972 and was opened to visitors on 28th July 1982. Its exhibition, which was re-organized in a chronological order in 2010, was opened to visitors in June 2011. This building was, however, severely damaged during the earthquake in the region of Elazığ on 24th January 2020, and consequently, the museum was moved to another building.

The main collection of the museum consists of artefacts and monuments from the third and second millennia B.C. which originate mostly from the local rural mound sites. The number of Roman artefacts in this museum is c. 100, excluding numismatic finds; information concerning the original provenance is, however, lacking for most of these finds. ${ }^{6}$

In this brief paper we will focus on an inscribed sarcophagus from this museum which is perhaps the only inscribed object in Greek in this museum or indeed in this part of eastern Turkey. ${ }^{7}$

\section{A Greek inscription on a Roman sarcophagus in the Museum of Elazığ (Figs 1-6)}

Accession number and repository. Accession no. 9. The low accession number suggests the sarcophagus was acquired by the Elazığ Museum early in its history, perhaps in mid-1960s. It is currently exhibited in the garden of the museum. Since the earthquake in 2020, it leans upon another stone object so that the inscribed short side cannot be completely documented.

Provenance. Unknown, but probably brought from Harput or from a höyük site in the region during the late 19th century. It must have originally stood in a Roman cemetery in an ancient site which is difficult to identify. Given the proximity of Roman-era Charpete (Harput), it was probably brought in from a cemetery of this ancient site.

\footnotetext{
On Sophene, see Frankfort 1963; Chaumont 1993, 434; Schottky 1989.

On Hellenistic culture in this region through historical sources, see Schottky 1989.

On the Arsacid dynasty and its end, see Bivar 1983, 92-97.

On Aşvan Kale, see Mitchell 1980.

On Taşkun Kale, see McNicoll 1983.

On the Roman finds in this museum, see Patacı and Laflı 2013.

For a sarcophagus from Commagene, see Facella 2008.
} 


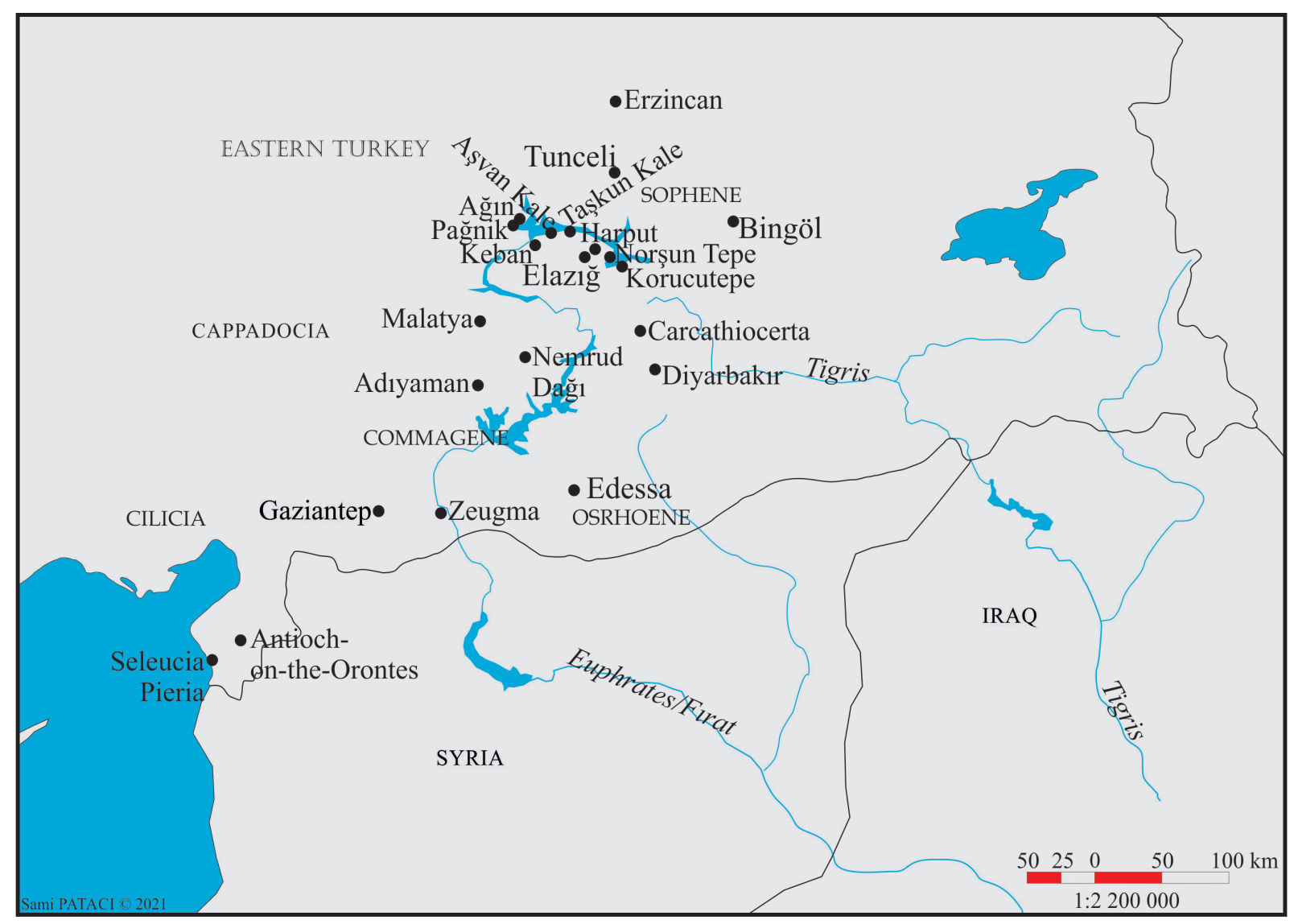

Map 1: Places in eastern Turkey referred to (by S. Patacl, 2021).

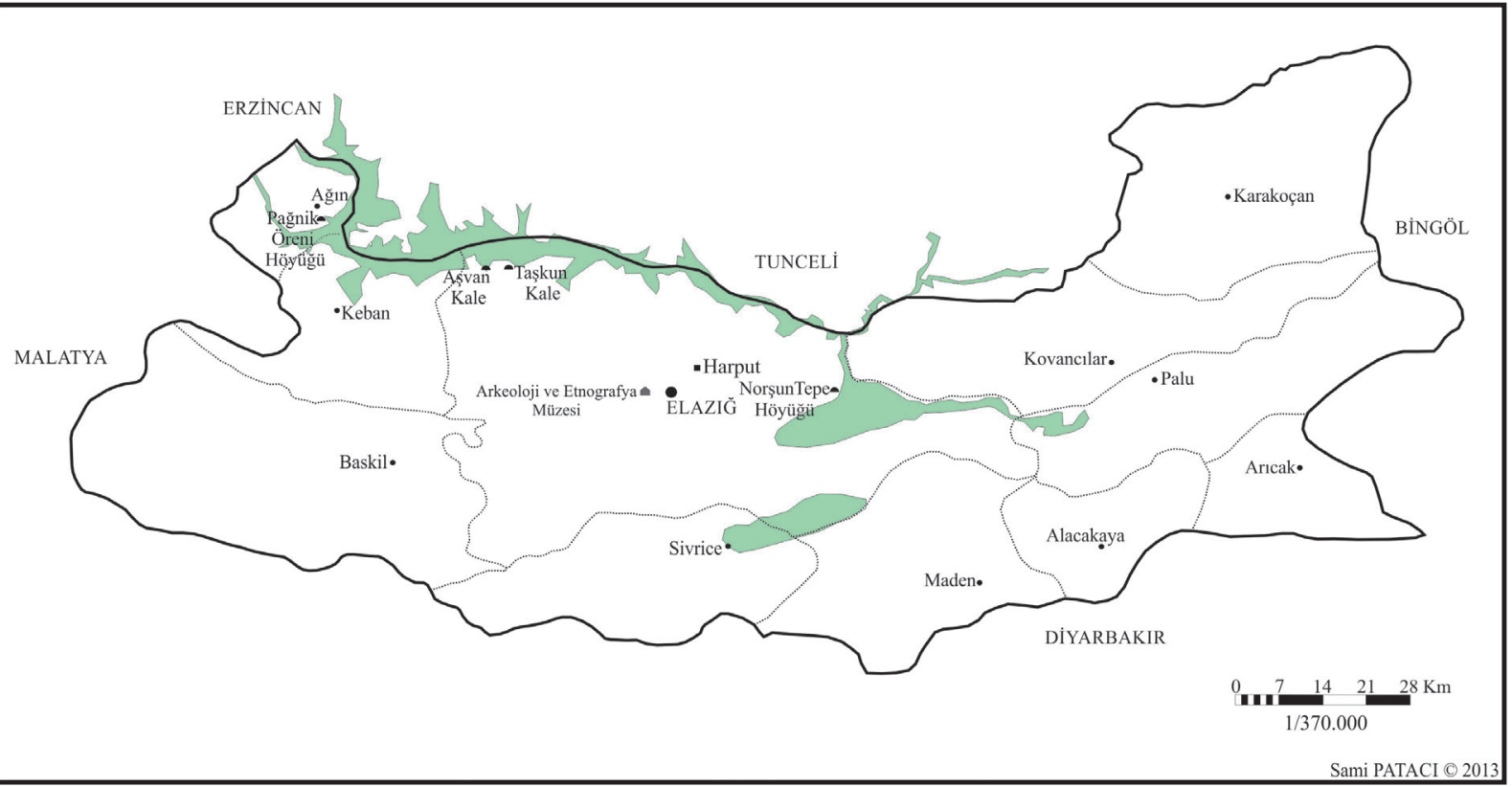

Map 2: Elazı̆̆ and its environs (by S. Patacı, 2021). 
Although there is no evidence in modern Harput for the existence of a Roman cemetery, it still seems the most probable source for this sarcophagus.

Material. Coarse, local, creamy, porous limestone. Identification of stone as local limestone is based upon a visual examination of the stone as creamy, fine grained and micaceous.

State of preservation. All the faces of this sarcophagus (which may have been used as a laundry tub, utility sink, watering trough, drinking basin for animals, feedbox for animals or bathtub for a long time) are severely damaged and worn from prolonged exposure to water. Most of the upper part of the coffin is lost; several decorative features are worn away and all carved details on the garlands are weathered. The right-hand corner of the inscribed long (front) face is completely missing. All four sides of the coffin were cut flat horizontally or levelled off during its period of multifunctional reuse. The surface of the stone is heavily pitted, abraded, weathered, flaky, covered with lichen and coated with a thick black deposit of pollution. There is a dark incrustation over most of the carved surfaces from being outside for an extended period of time. Most surface details including toolmarks have been obliterated. There is a roughly-cut almost circular hole $5.3 \mathrm{~cm}$ in diameter, which was cut during its period of reuse, on the front long side just below the tabula ansata.

Dimensions. Preserved max. height $46.2 \mathrm{~cm}$, length $186.1 \mathrm{~cm}$, width $66.8 \mathrm{~cm}$, max. thickness $19.3 \mathrm{~cm}$.

Typological description. Remains of a small, centrally placed, tabula ansata, with garlands and perhaps rosettes centered above the garland swags at both ends, are visible in the middle of one long side of the sarcophagus. The short sides also bear roughly-defined garlands which were carved in moderately high relief. Each corner is decorated by a pillar, which are not well-preserved. In Cappadocia, Galatia and eastern parts of Asia Minor garlands were especially popular on Roman ash chests and sarcophagi; this kind of decoration is very common on examples in local Turkish museums in these regions. Its thick base is roughly shaped. Decorative elements were less skillfully carved. Thus, the quality of carving on this sarcophagus is quite mediocre and these characteristics indicate a lesser and local quality of craftsmanship. Indeed, funerary monuments of the Graeco-Roman style in eastern Turkey reflect generally a low quality of production.

Inscription. There are Greek inscriptions on the long front face of the sarcophagus (beneath the left-hand garland) and the short left-hand side face (to the right of the garland). Traces suggest that at least part of the inscription wrapped around the corner of the sarcophagus, cutting across the pillar. The letters appear lightly incised into the surface of the stone and only traces of some letters are now discernible. Most of them are several crudely cut and irregularly placed. Faces (a) and (b) are divided by a pillar, which may contain the remains of letters (we note a round letter at line 6). The other short face (c) does not appear to be inscribed; the other long face (d) is not accessible.

Letters. C, $€, \omega$. Letter height: 1.9-2.7 cm (I, T, $€)$.

(a) Short face with 9 lines of inscription (Fig. 2):

(b) Long face

with 5 lines of

inscription (Figs 1, 3):

garland

$\ldots \Lambda \mathrm{O}$

garland

... $\Theta . M$

... $€$ PK€O

... traces ...

... НФҮГШ

... traces ... traces

5

... traces ...

$\mathrm{O}(?)$

KAT ...

$\ldots \mathrm{O} \triangle \mathrm{ONT} \omega$

5

TIC $\triangle$ YNACTHCKA $\Theta \omega C$

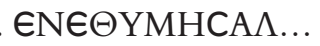

... $Є \Theta А П$

... NTO

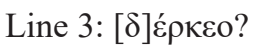

Line 4: خ̀ $\varphi \gamma \gamma \omega ́$ ?

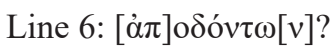

Line 8: $[\tau] \varepsilon \dot{\varepsilon} \theta \alpha \pi[\tau \alpha u]$ vel sim? 
The only part of the text that can be transcribed with even a low level of certainty are lines 6-7 of the long side, as follows:

$\tau 1 \varsigma \delta v v \alpha ́ \sigma \tau \eta \varsigma \kappa \alpha \theta \omega ́ \varsigma . .$.

$[\mathrm{M}] \varepsilon v \varepsilon \theta \dot{u} \mu \eta \varsigma \alpha \hat{\alpha} \lambda[v \pi \varepsilon]$

\section{Translation.}

Some dynast, even as...

Menethymes, missed...

\section{Türkçe Çevirisi.}

Bazı hükümdar, hatta...

Menethymes, özlenen...

Epigraphic comments. Owing to its fragmentary state of preservation, it is currently impossible to make sense of

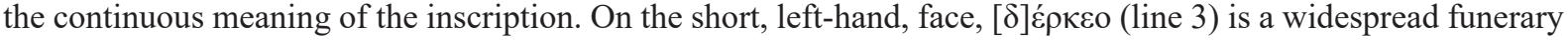

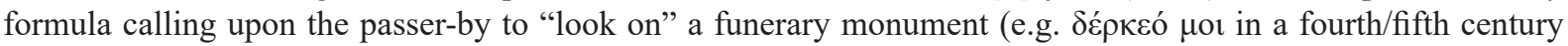
AD monument from Sinope, IK Sinope 181 line 9). In line 4, one possible reading is ì $v \gamma \gamma \omega ́$ ? ("or I flee"), but the reference is obscure. In line 6 , the reference of $[\dot{\alpha} \pi]$ o $\delta$ ó $v \tau \omega[v]$ ? ("let them sell") is again hard to understand;

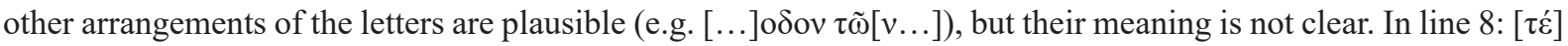
$\theta \alpha \pi\left[\tau \alpha_{1}\right]$ ("honoured with funeral rites") might be a reference to burial.

The long side is more revealing, and we suggest that a name can be deciphered on the front face: Menethymes. This name, or a similar form, Menethymos, is attested as a name in Kerkyra (SEG 48.645, third/second century BC)

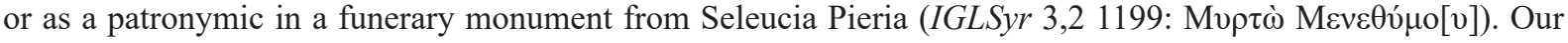
restoration of $\alpha \hat{\lambda}[v \pi \varepsilon]$ (which may have been followed by $\chi \alpha \tilde{\imath} \rho \varepsilon$ ) supports the interpretation of this as a funerary inscription. It is harder to envisage a context for $\tau \iota \varsigma \delta v v \alpha ́ \sigma \tau \eta \varsigma \kappa \alpha \theta \omega ́ \varsigma$. The term $\delta v v \alpha ́ \sigma \tau \eta \varsigma$ is attested in inscriptions of the wider area, for instance during the first century BC, in the shape of a royal edict from Commagene (IGLSyr 1 1: Nemroud Dagh) and a regulation (IGLSyr 1 51: from Sélik). $\tau \iota \varsigma \delta v v \alpha ́ \sigma \tau \eta \varsigma$ may possibly make reference to a member of the Arsacid dynasty, which was overthrown in AD $224 .{ }^{8}$ But certainty is impossible. Thus, it is not possible to determine to whom this funerary monument is commemorated.

Dating. On the basis of the letter forms it should be dated to the late second - early third century AD. The rendering of the garlands and pillar indicates workmanship of the second half of the second century AD; but the inscription is probably later than the sarcophagus.

Reference. Patac1 and Lafl1 2013, 814, no. 74, 820, pl. 6, figs 74a-f (picture only).

\section{Conclusion}

Overall, this inscribed sarcophagus appears to make use of some norms of Greek funerary language and attests to the presence of some Greek culture in the southwestern part of eastern Anatolia as late as the third century AD. ${ }^{9}$ During the Hellenistic and Roman periods in this part of Asia Minor many types of funerary or votive monuments are almost entirely unknown. The main types which are primarily seen in the area are group reliefs from tomb buildings, portrait altars and sarcophagi. The use of sarcophagi appears to be restricted to the privileged population and was not accessible to the majority of inhabitants. In Roman Cappadocia and eastern Galatia too, sarcophagi demonstrate the privileged status of those they commemorated; but our sarcophagus hardly gives evidence for privilege.

See above, note 1. On competing royal identities including those of the Arsacids, see Canepa 2018, 95-121.

9 For Greek as a language of the Parthian elite, see Olbrycht; in the Parthian empire generally, see Dąbrowa 2011, 153-164. 


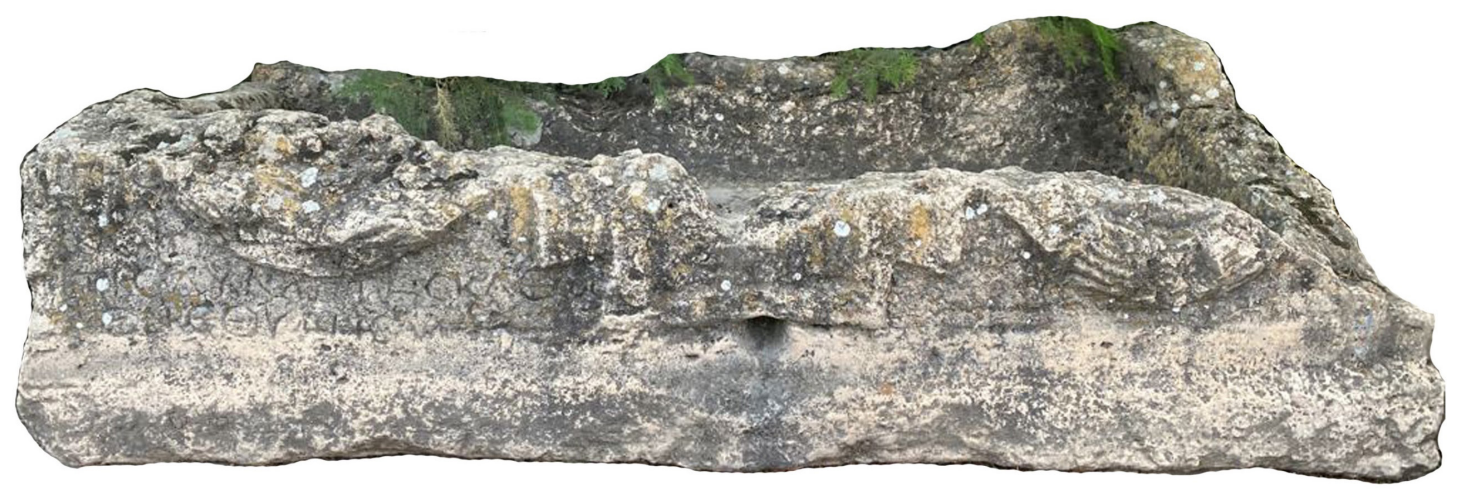

Fig. 1: An inscribed Roman sarcophagus in the Archaeological and Ethnographic Museum of Elazığ, accession no. 9 (by B. Çoşkun, 2021). Long face (b).

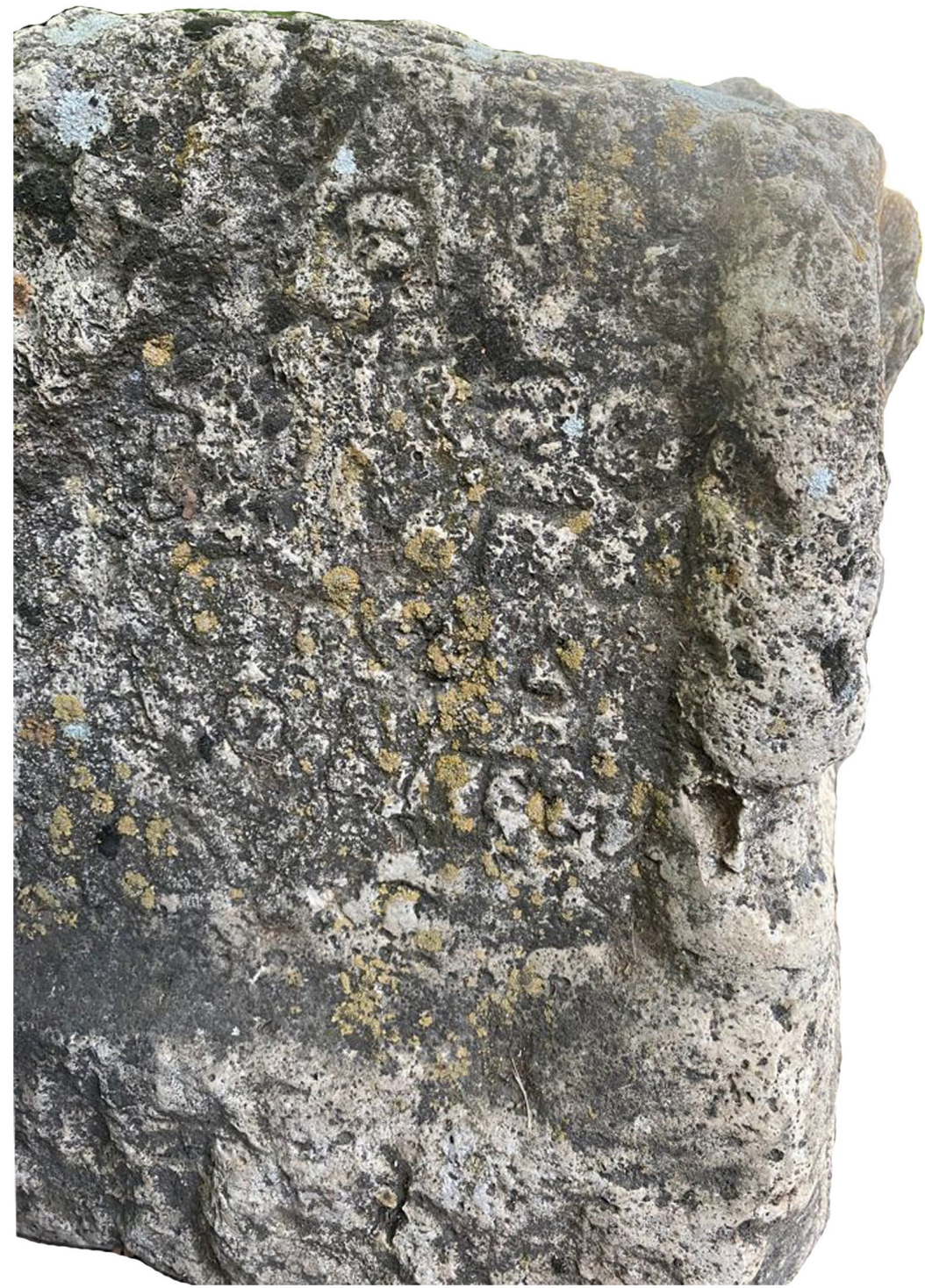

Fig. 2: An inscribed Roman sarcophagus in the Archaeological and Ethnographic Museum of Elazığ, accession no. 9 (by B. Çoşkun, 2021). Short face (a) 


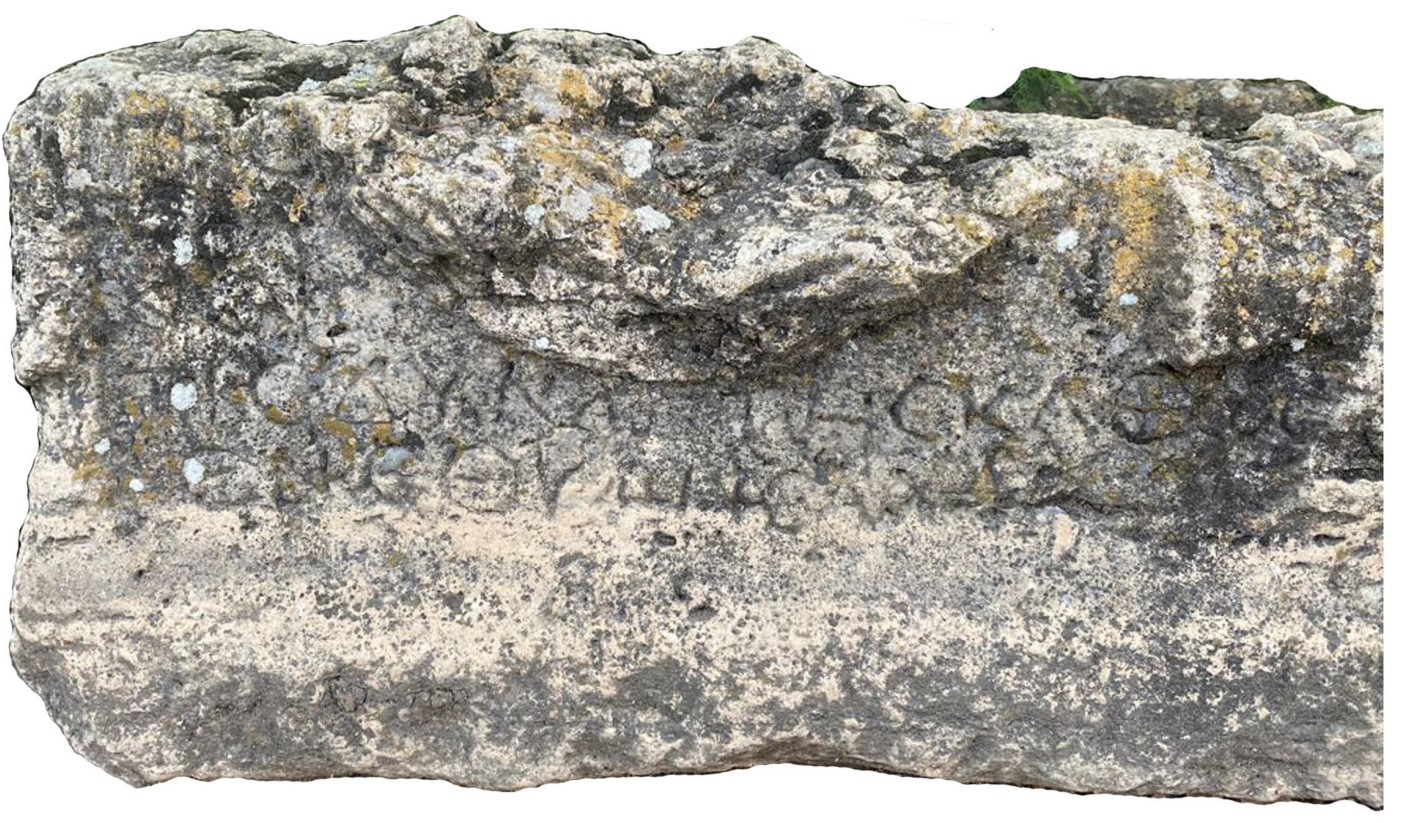

Fig. 3: An inscribed Roman sarcophagus in the Archaeological and Ethnographic Museum of Elazığ, accession no. 9 (by B. Çoşkun, 2021). Long face (b) (detail).

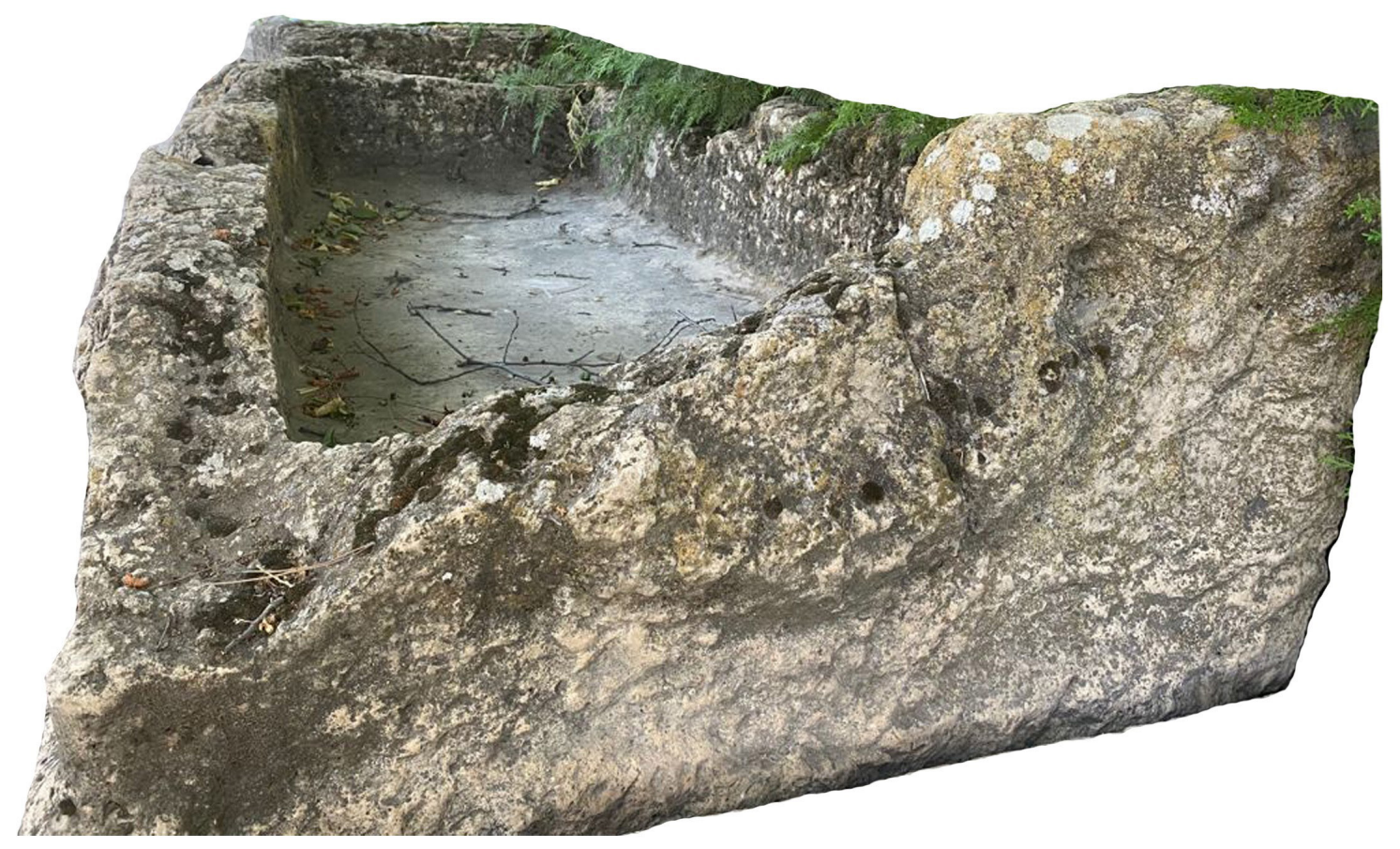

Fig. 4: An inscribed Roman sarcophagus in the Archaeological and Ethnographic Museum of Elazı̆̆, accession no. 9 (by B. Çoşkun, 2021). Short face (c). 


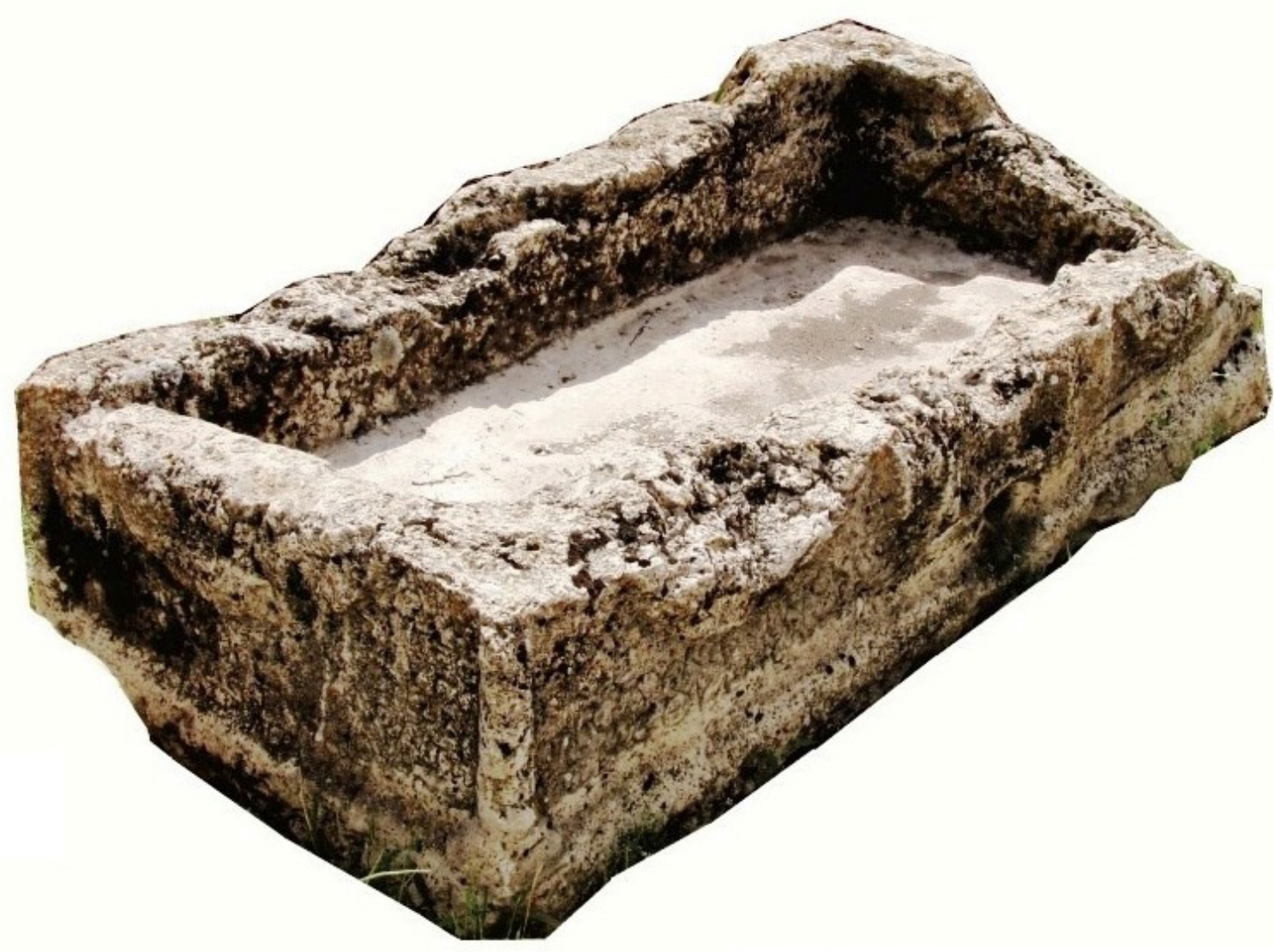

Fig. 5: An inscribed Roman sarcophagus in the Archaeological and Ethnographic Museum of Elazığ, accession no. 9 (by B. Çoşkun, 2021). Overall view from above.

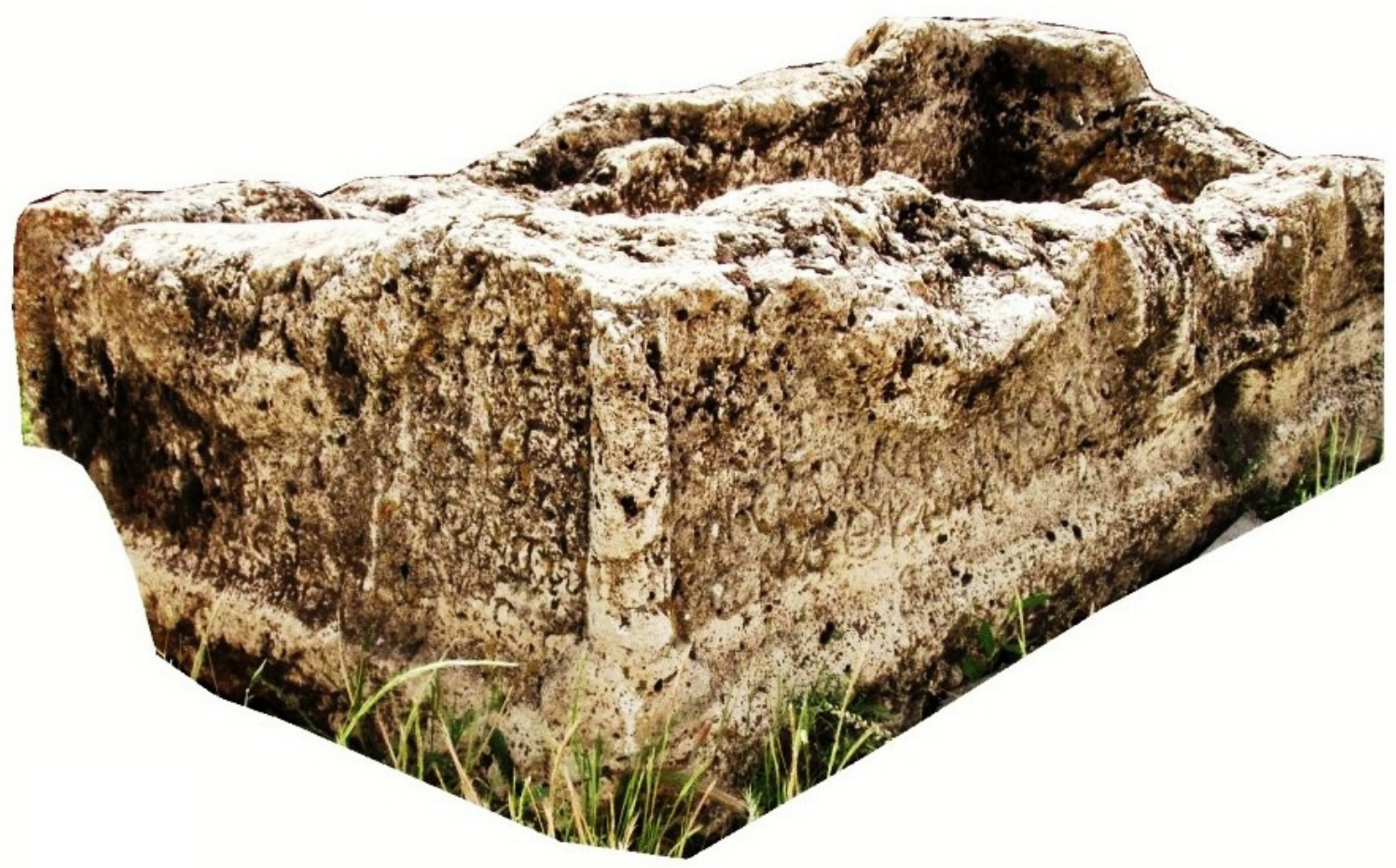

Fig. 6: An inscribed Roman sarcophagus in the Archaeological and Ethnographic Museum of Elazığ, accession no. 9 (by B. Çoşkun, 2021). Overall view. 


\section{Appendix: a Latin military inscription (Fig. 7)}

During the reign of Roman Emperor Nero in 64/65 AD, an inscription was erected in honour of a victory in $63 \mathrm{AD}$ of the Roman General Cn. Domitius Corbulo (AD 7-67), the brother-in-law of the emperor Caligula and fatherin-law of Domitian. This eight-line inscription on local yellow limestone on a base was made after the struggle between Rome and the regional powers of the Parthians and Tiridates. This Latin monument in Elazığ is the most important military inscription of the first century AD in the Roman Near East. It is published as CIL III 6741 and extensively revised in Dessau 1892, no. 232; cf. also Sherk 1988, no. 65B; Bru 2015; as well as Patac1 and Lafl1 2013, 814 , no. 73,820 , pl. 6 , fig. 73 (picture only).

Its transcription is uncontroversial: NERO CLAVDIVS / CAESAR AVG GERMANICVS / IMP PONT MAX TRIB POT XI / COS IIII IMP VIIII PAT P / CN DOMITIO CORBVLONE / LEG AVG PRO PR / T AVRELIO FVLVO LEG AVG / LEG III GAL.

Translation: "Nero Claudius Caesar Augustus Germanicus, Imperator, Pontifex Maximus, in his 11th year of Tribunician Power, Consul four times, Imperator nine times, Father of His Country. By Cnaeus Domitius Corbulo, Legatus Augusti pro praetore and Titus Aurelius Fulvus, Legate of Augustus of Legio III Gallica."

\section{Notes and acknowledgements}

The sarcophagus in the Archaeological and Ethnographic Museum of Elazı ğ was studied with an authorisation granted by the Directorship of this museum issued on 4 th June 2018 and registered as 34068228-155.01[155.01]E.481968. The necessary documentation was assembled in 2021 by Ms Birsen Çoşkun (Izmir), whom we thank

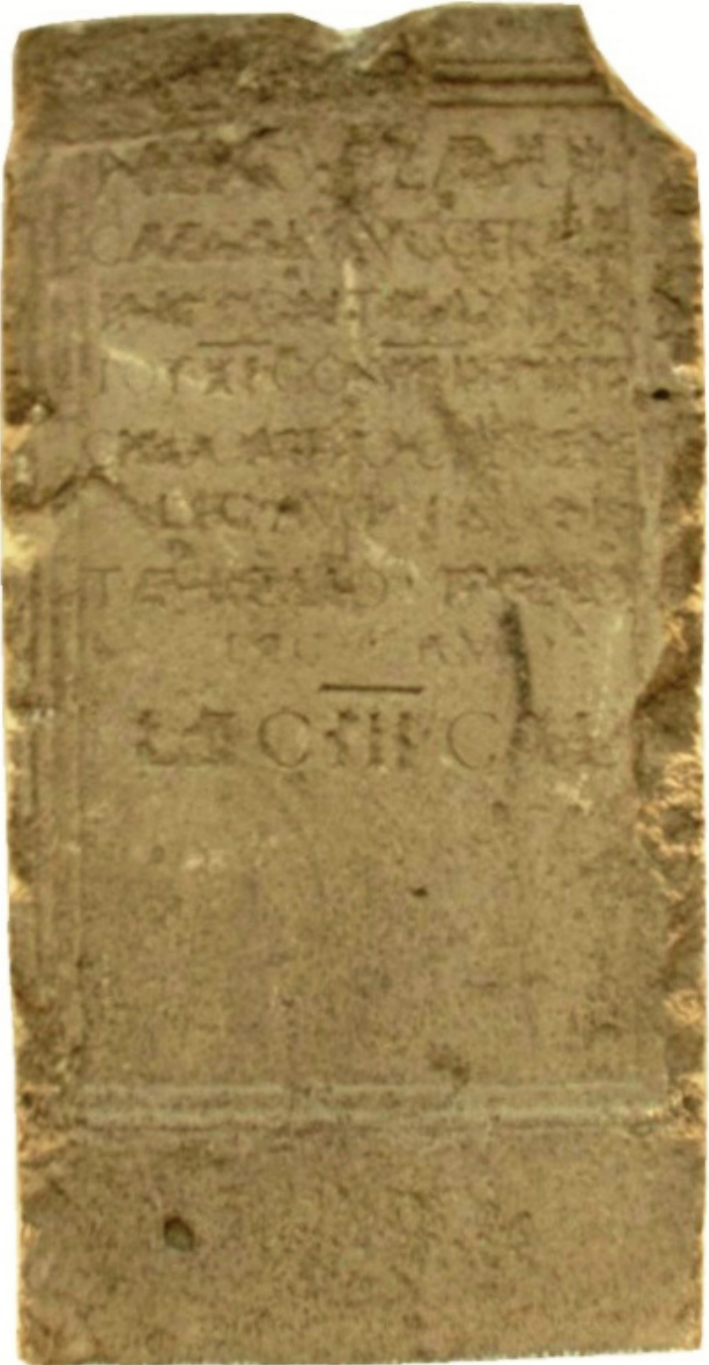

Fig. 7: A Latin military inscription in the Archaeological and Ethnographic Museum of Elazığ (by B. Çoşkun, 2021) for allowing us to publish her photos in this article. Her photos were re-arranged by Dr Gülseren Kan Şahin (Sinop), whom we would like to thank deeply. Dr Sami Patacı (Ardahan), to whom we express our sincere gratitude and appreciation, drew Map 1 and Map 2 in 2013 and 2021. We thank Professor Peter Thonemann (Oxford) for his comments on photographs of the inscription. We are also grateful to the editors of the Cercetări Arheologice for their constant support and patience. This article is dedicated to all of the victims of the Elazığ earthquake on 24th January 2020.

\section{REFERENCES}

Bru, H. 2015. A Latin military inscription in the Museum of Elazı̆̆ in E. Laflı and S. Patac1 (eds.), Recent studies on the archaeology of Anatolia, British Archaeological Reports, International Series 2750, 453-455, Oxford: Archaeopress.

Bivar, A.D.H. 1983. The political history of Iran under the Arsacids, in E. Yarshater (ed.), The Cambridge history of Iran, vol. 3: the Seleucid, Parthian and Sasanid periods, part 1, 21-99, Cambridge: Cambridge University Press. Canepa, M.P. 2018. The Iranian expanse: transforming royal identity through architecture, landscape, and the built environment, 550 BCE-642 CE, Oakland, CA: University of California Press.

Chaumont, M.-L. 1993. Fondations séleucides en Arménie méridionale, Syria 70/3-4: 431-441.

CIL: Corpus inscriptionum Latinarum (Berlin 1862-). 
Dąbrowa, E. 2011. Studia Graeco-Parthica: political and cultural relations between Greeks and Parthians, Philippika 49, Wiesbaden: Harrassowitz Verlag.

Dessau, H. 1892. Inscriptiones latinae selectae, vol. 1, Berlin: Weidmann.

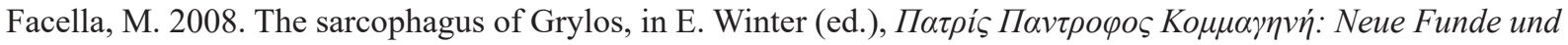
Forschungen zwischen Taurus und Euphrat, Asia Minor Studien 60, 201-205, Bonn: R. Habelt.

Frankfort, T. 1963. La Sophène et Rome, Latomus 22/2, 181-190.

IGLSyr 1: L. Jalabert and R. Mouterde (eds.), Inscriptions grecques et latines de la Syrie, vol. 1: Commagène et Cyrrhestique, Bibliothèque archéologique et historique 12 (Paris: P. Geuthner, 1929).

IK Sinope: D.H. French, The inscriptions of Sinope, Inschriften griechischer Städte aus Kleinasien 64 (Bonn: R. Habelt, 2004).

McNicoll, A. 1983. Taşkun Kale: Keban rescue excavations, eastern Anatolia, British Archaeological Reports, International Series 168; British Institute of Archeology at Ankara, Monograph 6, Oxford: British Archaeological Reports.

Mitchell, S. 1980. Aşvan Kale: Keban rescue excavations, eastern Anatolia, British Archaeological Reports, International Series 80, British Institute of Archeology at Ankara, Monograph 1, Oxford: British Archaeological Reports.

Olbrycht, M.J. 2017. Greeks in the Arsacid Empire, in J. Wiesehöfer and S. Müller (eds.), Parthika. Greek and Roman authors' views of the Arsacid empire / Griechisch-römische Bilder des Arsakidenreiches, Classica et Orientalia 15, 3-28, Wiesbaden: Harrassowitz Verlag.

Patacı, S. and Lafl1, E. 2013. Elazı̆̆ Müzesi'nden Bir Grup Roma Devri Buluntusu [A group of Roman finds at the Museum of Elazığ], in E. Çakar (ed.), Geçmişten Geleceğe Harput Sempozyumu, Elazığ 23-25 Mayıs 2013, Bildiriler, [Proceedings of the symposium on Harput from the past to the future, Elazığ, $23-25$ May 2013], Firat Üniversitesi Harput Uygulama ve Araştırma Merkezi, vol. 2, 807-820, Elazığ: İlhan Ofset-Matbaa.

Schottky, M. 1989. Media Atropatene und Groß-Armenien in hellenistischer Zeit, Habelts Dissertationsdrucke, Reihe Alte Geschichte 27, Bonn: R. Habelt.

SEG: Supplementum epigraphicum graecum, vols. 1-11, ed. J.E. Hondius (Leiden 1923-1954). Vols. 12-25, ed. A.G. Woodhead (Leiden 1955-1971). Vols. 26-41, eds. H.W. Pleket and R.S. Stroud (Amsterdam 1979-1994). Vols. 42-44, eds. H.W. Pleket, R.S. Stroud and J.H.M. Strubbe (Amsterdam 1995-1997). Vols. 45-49, eds. H.W. Pleket, R.S. Stroud, A. Chaniotis and J.H.M. Strubbe (Amsterdam 1998-2002). Vols. 50-, eds. A. Chaniotis, R.S. Stroud and J.H.M. Strubbe (Amsterdam 2003-).

Sherk, R.K. 1988. The Roman empire: Augustus to Hadrian, Translated documents of Greece and Rome 6, Cambridge etc.: Cambridge University Press.

ERGÜN LAFLI

Dokuz Eylül Üniversitesi, Edebiyat Fakültesi, Arkeoloji Bölümü elafli@yahoo.ca

PETER LIDDEL Department of Classics, Ancient History, Archaeology and Egyptology, University of Manchester peter.liddel@manchester.ac.uk 